\title{
Slowing down as we age: aging of the cardiac pacemaker's neural control
}

\author{
Sabrina Choi • Matthias Baudot • Oscar Vivas • \\ Claudia M. Moreno
}

Received: 10 March 2021 / Accepted: 7 July 2021 / Published online: 22 July 2021

(C) The Author(s) 2021

\begin{abstract}
The cardiac pacemaker ignites and coordinates the contraction of the whole heart, uninterruptedly, throughout our entire life. Pacemaker rate is constantly tuned by the autonomous nervous system to maintain body homeostasis. Sympathetic and parasympathetic terminals act over the pacemaker cells as the accelerator and the brake pedals, increasing or reducing the firing rate of pacemaker cells to match physiological demands. Despite the remarkable reliability of this tissue, the pacemaker is not exempt from the detrimental effects of aging. Mammals experience a natural and continuous decrease in the pacemaker rate throughout the entire lifespan. Why the pacemaker rhythm slows with age is poorly understood. Neural control of the pacemaker is remodeled from birth to adulthood, with strong evidence of agerelated dysfunction that leads to a downshift of the pacemaker. Such evidence includes remodeling of pacemaker tissue architecture, alterations in the innervation, changes in the sympathetic acceleration and the parasympathetic deceleration, and alterations in the responsiveness of pacemaker cells to adrenergic and cholinergic modulation. In this review, we revisit the main evidence on the neural control of the pacemaker at the tissue and cellular level and the effects of aging on shaping this neural control.
\end{abstract}

S. Choi · M. Baudot · O. Vivas · C. M. Moreno $(\bowtie)$

Department of Physiology \& Biophysics, University

of Washington, Seattle, WA 98195, USA

e-mail:morenocm@uw.edu
Keywords Heart rate - Cardiac pacemaker .

Autonomic control $\cdot$ Cardiac aging
Abbreviations
AC Adenylyl cyclase
$\beta$-AR Beta adrenergic receptor
cAMP Cyclic adenosine monophosphate
HCN Hyperpolarization-activated cyclic nucleo- tide-gated channels
$I_{\mathrm{f}} \quad$ Funny current (HCN)
IVC Inferior vena cava
M2R Muscarinic receptor type 2
NCX Calcium-sodium exchanger
PKA Protein kinase A
RA Right atrium
RyR Ryanodine receptor
SAN Sinoatrial node
SVC Superior vena cava

\section{Introduction}

On average, the human heart beats 100,000 times a day. Every heartbeat starts with a subtle electrical spark inside the sinoatrial node, a small and highly specialized tissue located next to the right atrium also known as the cardiac pacemaker. The automaticity of the cardiac pacemaker relies on the unique ability of its cells to continuously generate action potentials, starting very early during embryonic development and working non-stop until the moment we die. 
Despite the remarkable reliability of this tissue, the pacemaker is not exempt from the detrimental effects of aging [1]. Mammals, including humans and mice, experience a natural and continuous decrease in the intrinsic pacemaker rate throughout their entire lifespan (Fig. 1) [2, 3]. The intrinsic pacemaker rate declines linearly from birth at a rate of $\sim 0.8 \mathrm{bpm} /$ year in humans and $\sim \mathrm{bpm} /$ month in mice [3]. The slowdown of the intrinsic pacemaker rate is the main cause for the accompanying decline in maximum heart rate, playing a significant role in the loss of aerobic capacity in older adults. In pathological cases, this slowdown results in arrhythmia and sometimes sudden death as part of a group of idiopathic disorders known as Sick Sinus Syndrome [4]. This syndrome is the main cause for more than 600,000 artificial pacemaker implantations carried out annually in the world [5]. Hence, aging is the leading risk factor for heart pacemaker dysfunction, which justifies the urgency of understanding the pacemaker's age-dependent decline. Although some of the mechanisms behind the pacemaker slowdown are being elucidated, there are still many unanswered questions.

Heart rate is finely tuned through neural control to maintain body homeostasis in constantly changing conditions. Slight internal changes in blood volume, $\mathrm{CO}_{2}$ levels, or $\mathrm{pH}$ trigger the activation of autonomic reflexes that directly modulate the intrinsic firing rate of pacemaker cells. In addition, pacemaker rate is abruptly changed in response to external stimuli as part of the fight-or-flight response activated under acute stress [1,6]. Neural control of the pacemaker is achieved by a dense innervation, making the pacemaker the most innervated region of the heart [7]. The direct action of autonomic innervation on the firing of the pacemaker was first visualized by Otto Hutter and Wolfgang Trautwein in 1955, pioneers in the pacemaking field. Hutter and Trautwein photographed, for the first time ever, traces showing vagal stimulation depressed the pacemaker firing while stimulation with atropine accelerated it [8]. Since then, questions regarding pacemaker modulation, its pattern of innervation, and the disease-related changes in the neural control of the pacemaker have been further researched.

As shown in Fig. 1, heart rate varies with age, with a rapid decrease in resting heart rate from birth till late childhood, and a parallel linear decline in the maximum and the intrinsic pacemaker rate throughout the entire life $[2,9]$. Age-associated changes in the resting heart rate depend mainly on the remodeling of the pacemaker's neural control. During the first years after birth, there is a predominant sympathetic drive that maintains high resting rate values.
Fig. 1 Comparison of maximum, intrinsic, and resting heart rates along human lifespan, illustrating the effect of age on the sympathetic and parasympathetic drive. The Intrinsic heart rate declines linearly from birth at a rate of $\sim 0.8 \mathrm{bpm} /$ year in humans [3]. Data to build the graph was obtained from Marcus et al. [9], Ostchega et al. [2], and the AHA

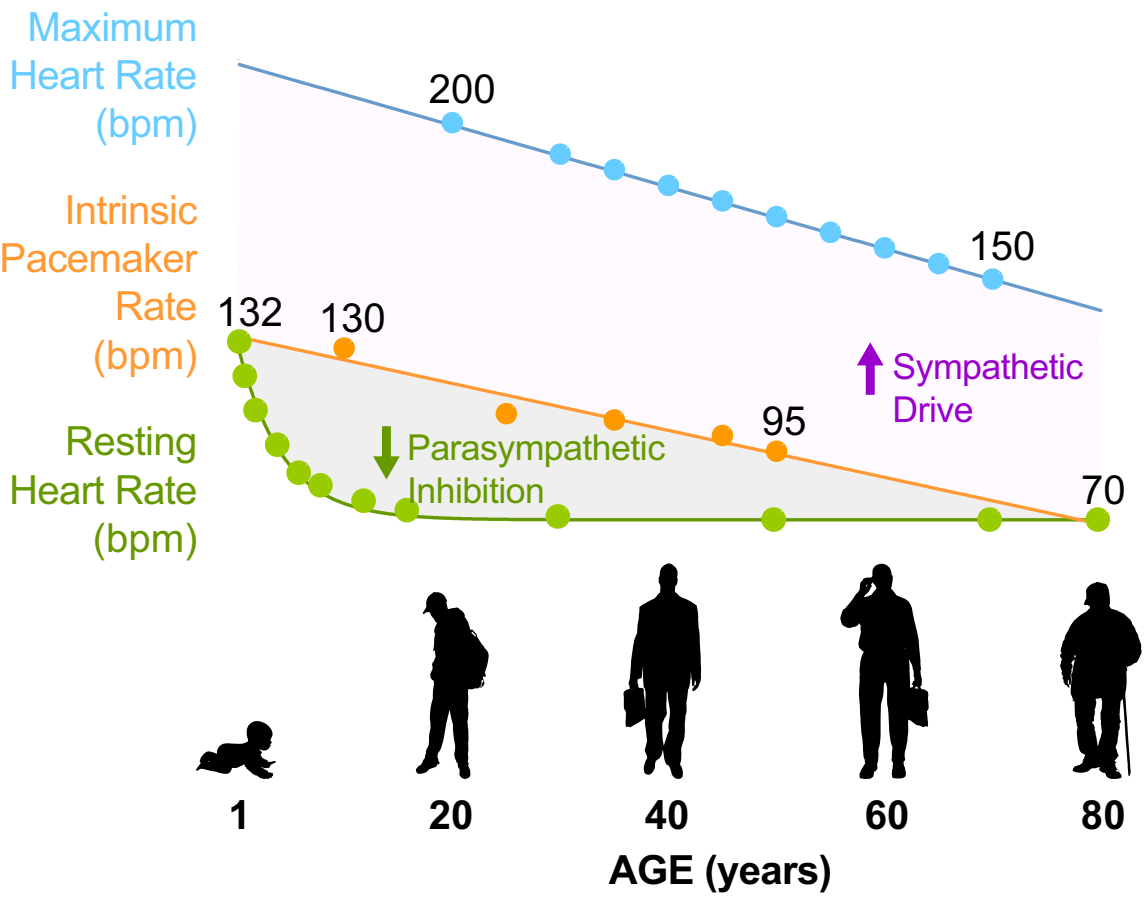


However, throughout childhood, the parasympathetic tone increases and becomes predominant, setting lower resting rates that remain relatively stable throughout the lifespan.

In contrast, the age-associated linear decline in the intrinsic heart rate has been proposed to be caused by a combination of intrinsic and extrinsic mechanisms. Some of the identified intrinsic mechanisms behind the slowdown of the intrinsic pacemaker rate include (i) the reduction in the activation of the funny current $\left(I_{f}\right)$ carried by HCN channels, which is one of the main ionic currents sustaining the pacemaker automaticity $[3,10]$, (ii) a tissular remodeling driven by the loss of pacemaker cells [11-13], and (iii) a reduction in the sensitivity of pacemaker cells to adrenergic modulation. We refer the readers to a comprehensive review recently published by Peters et al. [1] covering these three main aspects. Extrinsic mechanisms linked to the age-associated pacemaker slowdown include an increase in tissue fibrosis and changes in the sympathetic/parasympathetic balance. There is evidence that aging causes an important remodeling in the sympathetic and parasympathetic modulation and the response of pacemaker cells to it. Despite the evident remodeling of the neural control of pacemaker function, little is known about how aging affects the innervation of the pacemaker and the neuro-pacemaker communication. Here, we will revisit the main evidence on the neural control of the pacemaker at the tissue and cellular levels and the effects of aging on shaping this neural control.

\section{Pacemaker anatomy and structural alterations during aging}

The cardiac pacemaker was anatomically identified in 1907 by Arthur Keith and Martin Flack. Only a select group of studies have such an impressive list of materials like that from Keith and Flack's original paper [14]. By analyzing hearts from eels, salmon, frogs, lizards, turtles, moles, mice, cats, a kangaroo, a dolphin, humans, and even a whale, Keith and Flack identified inside the sino-auricular junction a conserved region of characteristic primitive wavy fibers which exhibited a close connection with the terminals innervating the heart. This led them to hypothesize that this region was the origin of the heart's rhythm and the main target for the heart's neural control; further studies would prove them right [15-17]. The pacemaker is located next to the right atrium and delimited to the left by the crista terminalis, to the bottom by the inferior vena cava, and to the top by the superior vena cava (Fig. 2). Size and position vary between species, but it is always delimited to the intercaval region [18]. Occupying only about $3 \%$ of the heart surface area [19], the pacemaker drives the contraction of the whole heart. Opposite to the large and highly organized cells that form the ventricles and atria, the pacemaker is formed by small wavy cells with poor content of myofibers immersed into a dense connective tissue network [20,21]. The proper function of the pacemaker relies on its architecture [18]. Far from being a homogeneous structure, the pacemaker is formed by at least three morphologically different cell types, classified as spindle, elongated, and spider cell-types [22-24]. These cells are organized into a complex tridimensional structure divided into a head and a tail region (Figs. 2 and 3A). Although it is not yet clear how these three cellular subtypes organize inside the pacemaker or if they play different roles in the generation and conduction of the electrical signals, there is evidence in rabbits [25], dogs, and humans [26] that spindle cells inside the head of the pacemaker organize to form the pacemaker lead. The lead initiates the electrical signal that propagates through the pacemaker and travels along the electrical conduction system of the heart to trigger the contraction of the heart chambers [27]. The pacemaker tail, also called the peripheral area, is composed of less packed pacemaker cells running in a caudal direction (Fig. 2 and 3A). In some species, there is a gradual transition with pacemaker cells interspersed with atrial-like cells [18]. The tail plays an important role in the propagation and the exit of the electrical signal towards the right atrium. Electrical continuity is important for the conduction of the electrical signals. As such, pacemaker cells are connected through gap junctions formed by connexins 45,40 , and 30.2 to secure the rapid spread of the signal $[18,28-30]$. Interestingly, cells at the center of the pacemaker do not connect to a vast extent, suggesting that they have a very specialized and efficient electrical coupling [31]. Given the high metabolic activity of this tissue, the pacemaker is highly vascularized, being supplied directly by the sinoatrial node artery and a vast arteriole and capillary network (Fig. 3B). 
a

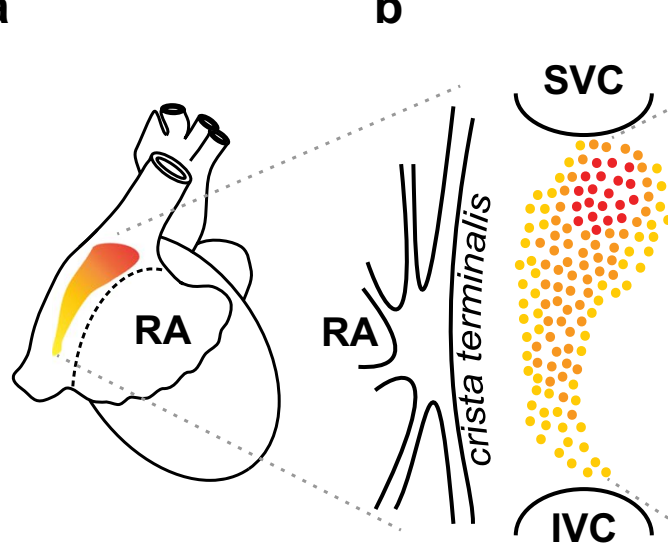

C

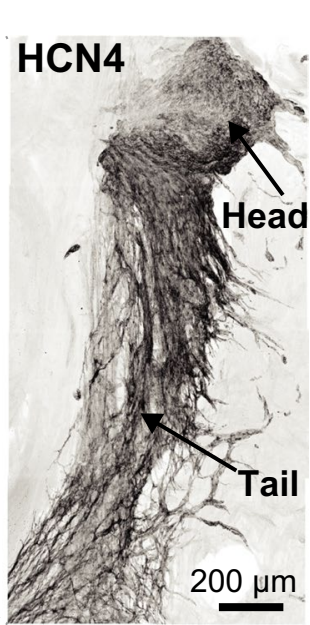

Fig. 2 a Anatomical localization of the cardiac pacemaker next to the right atrium (RA). b Representation of the ventral view of the cardiac pacemaker delimited by the crista terminalis, the superior (SVC), and inferior vena cava (IVC). c. Representative super-resolution image of a cleared pacemaker from a 6-month-old mouse. Tissue was immunostained with the anti-HCN4 marker for pacemaker cells. Positive labeling is depicted in the inverted gray-scale image. The head and the tail regions of the pacemaker are indicated with the arrows
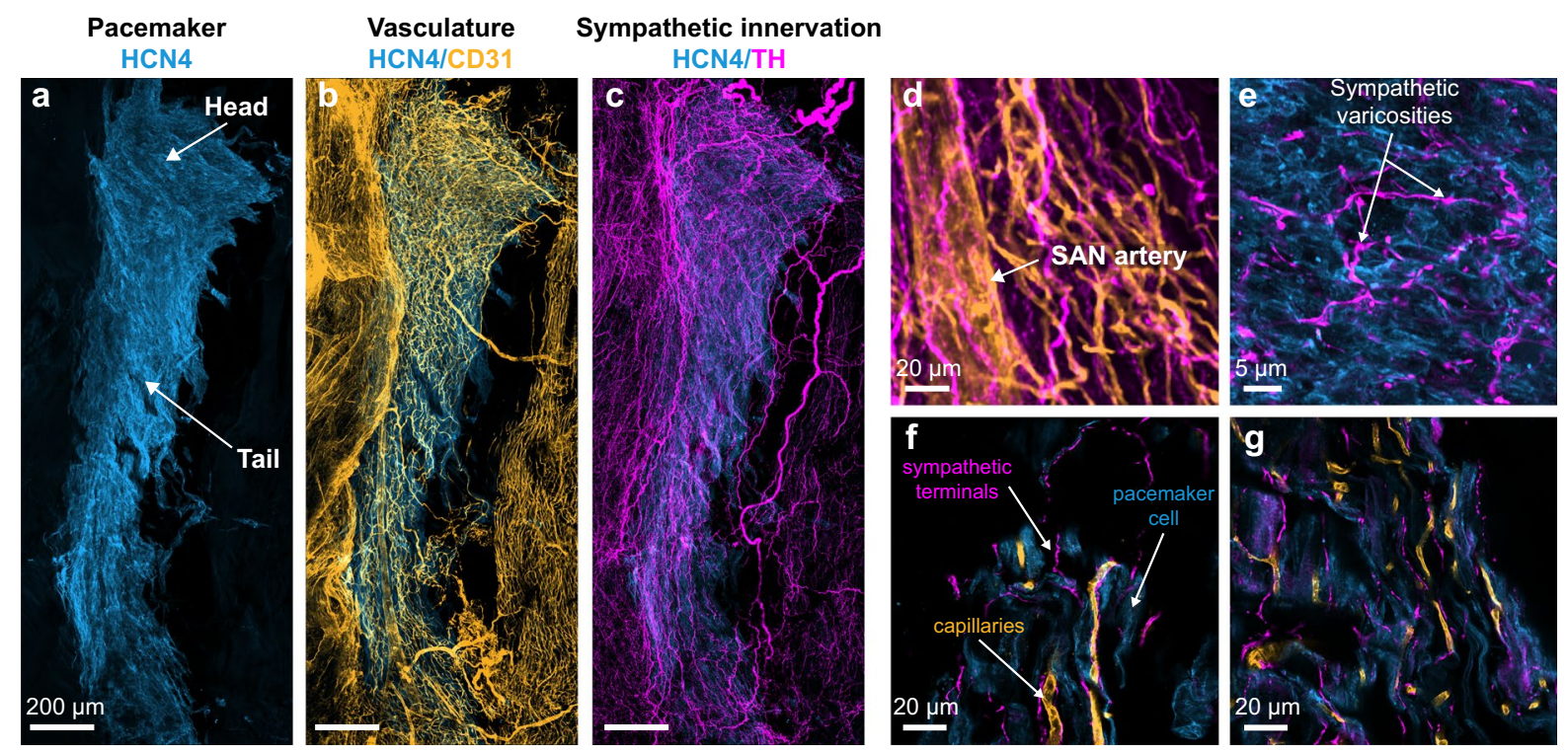

Fig. 3 Representative 10X AiryScan super-resolution reconstruction of the mouse pacemaker. The pacemaker was isolated from a 4-month-old animal and immunostained against a the pacemaker marker HCN4 channel (blue), b the vascular marker CD31 (orange), and c the sympathetic marker TH (magenta). d Magnification of the sinoatrial node (SAN) artery

Architectural remodeling of the pacemaker tissue has been suggested as one of the factors leading to its dysfunction during aging. The main age-associated (orange) and the sympathetic innervation of the vasculature (magenta). e Magnification to show the sympathetic axonal varicosities (magenta) in close contact with the pacemaker cells (blue). $\mathbf{f}-\mathbf{g} 63 \mathrm{X}$ magnifications of two pacemaker regions to show the intricate contacts between the sympathetic terminals, the vascular tree, and the pacemaker cells

changes include changes in cell size, cell number, and fibrosis. Both cell atrophy [13] and hypertrophy $[3,32,33]$ have been observed in old animals, so 
the association between cell size and dysfunction is still inconclusive. The number of pacemaker cells is inversely proportional to age [11, 34], and, in some cases, the amount of fibrotic tissue is positively correlated with age [11-13, 35]. However, fibrosis has also been observed in healthy individuals, suggesting that fibrosis does not necessarily lead to pacemaker dysfunction [35, 36]. Another common age-associated architectural change is the infiltration of fatty tissue, but its role in pacemaker dysfunction remains unknown [13]. Given the high metabolic demand of the pacemaker, another important and unexplored aspect is how aging affects the vascularization of the pacemaker.

\section{Autonomic heart rate modulation and aging}

In order to understand the heart rate neural control, it helps to visualize the pacemaker as a car driving at a constant speed that can be overridden by pressing the accelerator or the brake. In the absence of any external input, the constant speed of the car is equivalent to the so-called intrinsic heart rate, which is dictated by how fast the pacemaker cells can fire action potentials. The accelerator pedal represents the sympathetic neurons innervating the pacemaker, which, by the release of noradrenaline, accelerates the pacemaker up to the maximum heart rate. The brake represents the parasympathetic nerve terminals, which, through the release of acetylcholine, decreases the intrinsic rate to reach the minimum level, commonly referred to as the resting heart rate. Humans have a tonic parasympathetic activity that explains why our resting heart rate is about $70 \mathrm{bpm}$, even though human pacemaker cells have an intrinsic rate of approximately $100 \mathrm{bpm}$. Intrinsic, resting, and maximum heart rate varies between species, but the age-associated progressive decline is a common denominator (Fig. 4).

Pacemaker innervation

The pacemaker is the most innervated region of the heart, being innervated 3-4 times more than the surrounding atrial area $[37,38]$. It receives sympathetic and parasympathetic terminals coming from neurons

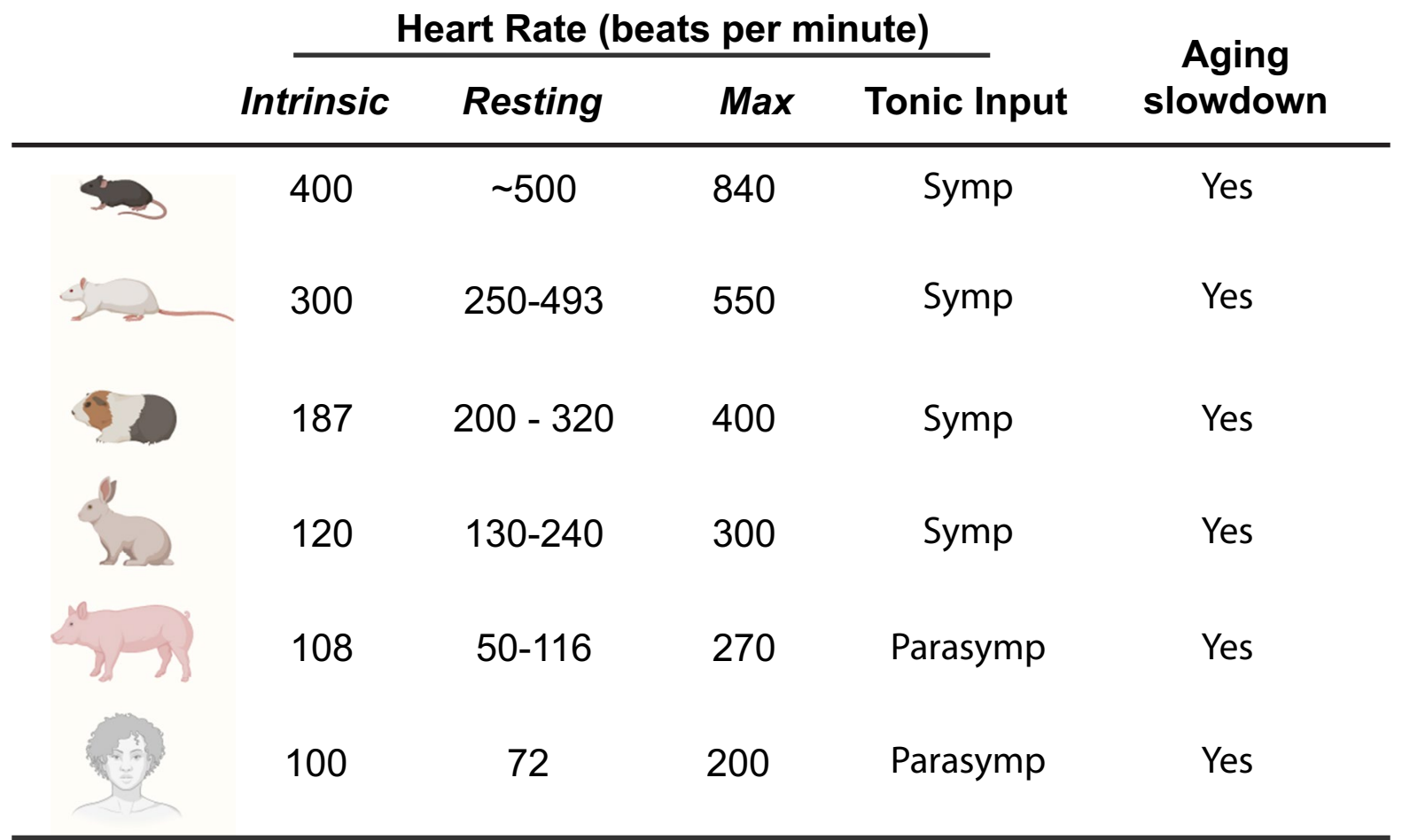

Fig. 4 Species-specific heart rate ranges, autonomic tone, and evidence of age-associated slowdown. Data for the different species were obtained from [1, 122-138]. Figure created with Biorender 
located in extracardiac and intracardiac ganglia [39]. While the extracardiac ganglia run parallel to the spinal cord and contain exclusively sympathetic neurons, the intracardiac ganglia are located in the interatrial surface [40] and contain a pool of afferent sensory neurons, interneurons, and efferent sympathetic and parasympathetic neurons [41]. We will not discuss in detail the morphology and function of the intracardiac nervous system here since a recent review on this topic by Fedele and Brand covers it extensively [42]. The dense nerve network interlaces with the complex pacemaker vascular bed and with the pacemaker cells (Fig. 3C and D). The sympathetic and parasympathetic axons have abundant varicosities (Fig. 3D), where the release of noradrenaline and acetylcholine occurs [43]. In contrast to most neurons, autonomic nerve terminals form "en passant" synapses, which lack any post-synaptic pacemaker counterpart [43]. However, there is still a debate on the exact nature of the neuro-pacemaker communication interphase.

The pacemaker innervation is remodeled from birth to adulthood. In infants, sympathetic innervation is predominant, which correlates with the higher heart rates observed at that stage (Fig. 1). Parasympathetic nerve density increases during childhood until reaching a similar abundance to that seen for sympathetic nerves during adulthood [38]. Aging causes a reduction in both sympathetic and parasympathetic nerve density of the pacemaker [38]. Loss of sympathetic innervation has also been observed in other target tissues, including the pineal gland [44] and the spleen [45]. The remaining sympathetic nerves in these organs are swollen and contain aggregates and degenerating organelles. In the pineal gland, for example, the ratio of dystrophic axons to target pinealocytes increased by 30 -fold in 5-months-old to 23 -monthsold male rats and by 200 -fold in female rats. Interestingly, gender differences have been observed at the functional and morphological levels in the pineal gland [44]. More studies are needed to understand how aging affects the neuroanatomy of the sympathetic terminals directly in the pacemaker. Regarding the parasympathetic innervation, there is evidence of a loss of parasympathetic preganglionic neurons in the dorsal vagal nucleus and nucleus ambiguus on the right side of the medulla, which are the nuclei innervating the heart [46]. Although the number of intracardiac parasympathetic neurons does not change with age [47], a $45 \%$ reduction in the synaptic-like contacts in old animals has been reported [48]. More studies are needed to understand the effects of aging on the neuroanatomy and communication of the parasympathetic network with the sympathetic terminals, the vasculature, and the pacemaker cells.

\section{Pacemaker's sympathetic acceleration}

Heart rate is accelerated by the direct action of noradrenaline released from sympathetic neurons that innervate the cardiac pacemaker. This positive chronotropic modulation is controlled by the cardio motor pathway (Fig. 5), starting with the activation of sensory neurons coming from extracardiac ganglia. These mechano- and chemoreceptors sense various stimuli, including changes in $\mathrm{pH}, \mathrm{CO}_{2}$, blood levels, and blood volume. Information is conveyed to excitatory neurons in the nucleus tractus solitarius located in the brain stem. From here, inhibitory and excitatory neurons synapse to the caudal and rostral ventrolateral medulla to control preganglionic excitatory neurons located in the intermediolateral nucleus at the spinal cord. The ultimate target is the postganglionic neurons residing in the sympathetic cervical and stellate ganglia $[49,50]$. These postganglionic neurons directly innervate the pacemaker cells and release the noradrenaline that accelerates the pacemaker intrinsic firing rate.

With age, the sympathetic nervous system becomes hyperactive. Microneurographic recordings have shown that the characteristic bursting activity of sympathetic nerves increases with age, from 40 bursts/100 heartbeats in 20-year-old men to 65 bursts/100 heartbeats in 65-year-old men [51-53]. The age-dependent increase in sympathetic activity is more prominent in women, being 2.5 -fold more pronounced than in men [54]. The increased firing activity of sympathetic nerves results in increased basal levels of noradrenaline in plasma. Noradrenaline levels increase with age, from $200 \mathrm{pg} / \mathrm{ml}$ in 20 -year-old men to $400 \mathrm{pg} / \mathrm{ml}$ in 65-year-old men [53, 55-57]. In conclusion, aging leads to increased activity of the sympathetic nervous system, resulting in more noradrenaline released from the nerve terminals into target organs, including the pacemaker. Since the increase in the release of noradrenaline from the nerve terminals does not stop the slowdown of the pacemaker, it has been suggested that sympathetic hyperactivity is a response to the loss of pacemaker sensitivity to the adrenergic 
Fig. 5 Representation of the cardio-motor pathway controlling heart rate. Mechano- and baroreceptors in carotid and aortic sinuses sense changes in $\mathrm{pH}$, blood levels, and blood volume, and transmit information to nuclei in the medulla oblongata. Sympathetic innervation on the pacemaker originates from postganglionic neurons in the sympathetic ganglion chain. The parasympathetic pathway via the vagus nerve synapses with intracardiac ganglia (ICG) on the interatrial region to finally innervate the pacemaker

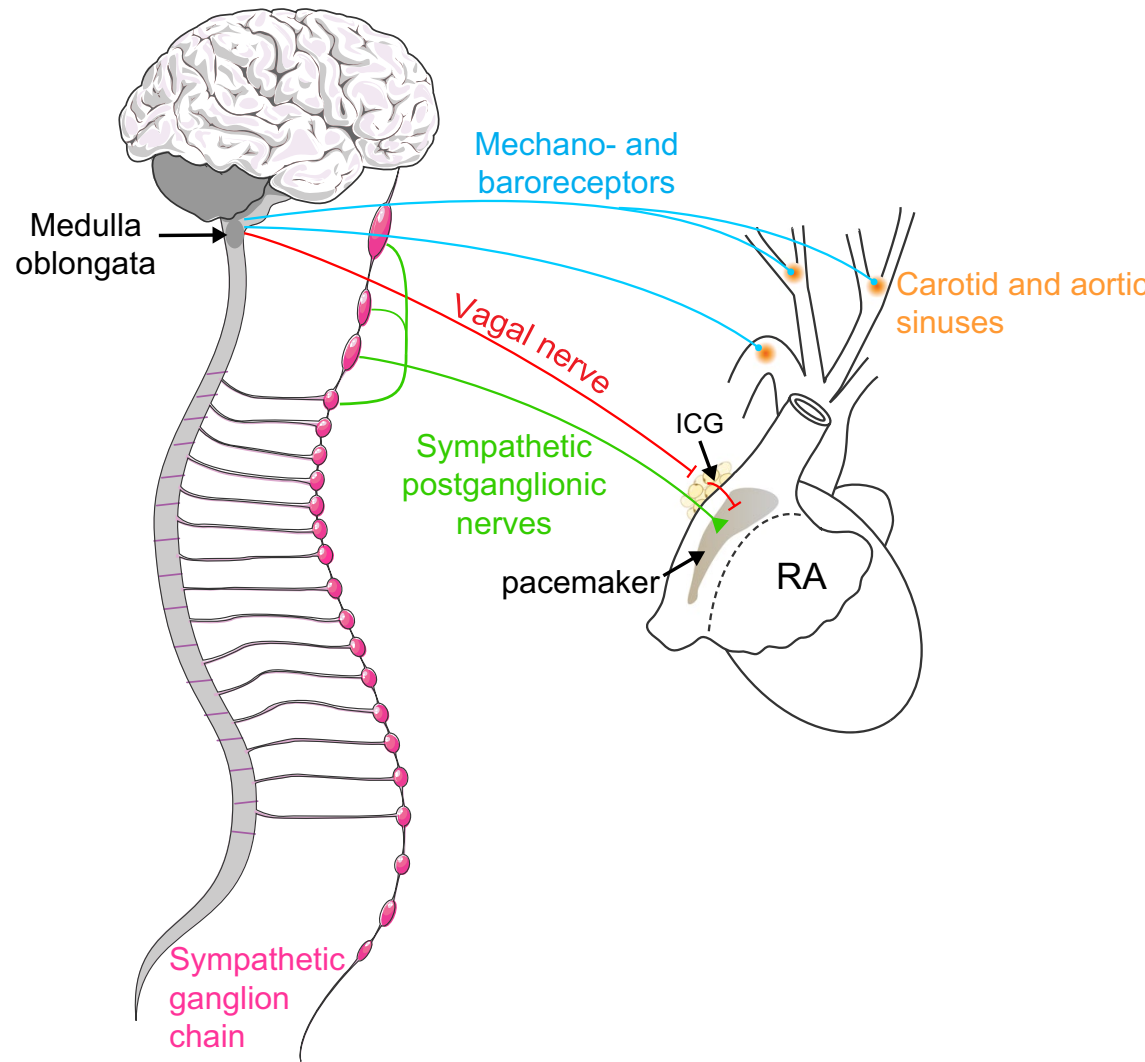

drive. The reason for this hyposensitivity might be a combination of reduced innervation and changes in the molecular mechanisms that sense the adrenergic signaling inside the pacemaker cells [58, 59].

Pacemaker's parasympathetic deceleration

In an antagonistic manner, heart rate is decelerated in response to the activation of the parasympathetic nervous system (Fig. 5) [60]. Opposite stimuli from those activating the sympathetic pathway also come from extracardiac mechano- and chemoreceptors, activating parasympathetic preganglionic neurons located in the medulla oblongata, specifically at the dorsal vagal nucleus and the nucleus ambiguous, from which the parasympathetic vagus nerve arises. The axons traveling through the vagus nerve directly innervate parasympathetic postganglionic neurons located at the intracardiac ganglia on the surface of the interatrial region. Parasympathetic terminals form synapses directly with sympathetic neurons to inhibit noradrenaline release through the release of acetylcholine. In addition, acetylcholine also acts over pacemaker cells to reduce their intrinsic firing rate.

Aging has an effect on pacemaker parasympathetic modulation. A reduction in the parasympathetic tone occurs with age and it has been suggested to compensate for the pacemaker intrinsic slowdown [61, 62]. Heart rate variability, which is largely accepted to reflect the parasympathetic modulation of the heart, decreases by more than $60 \%$ from 20 -year-old to 60-year-old subjects [63-65], suggesting a loss of parasympathetic tone with age. Interestingly, a biological model has been proposed to explain the decrease in heart rate variability. The Neuron-Immune-Senescence Integrative Model links brain degeneration of the central parasympathetic regions with a decreased activity in the peripheral parasympathetic nerves that innervate targets including the heart, leading to a reduced heart rate variability [66]. Interestingly, this model goes beyond the effect on the heart and suggests that reduced activity of the parasympathetic nervous system results in increased production of proinflammatory cytokines IL-6 and $\mathrm{TNF} \alpha$, leading to cellular senescence and affecting the whole organism 
and, therefore, influencing multiple disorders associated with aging. We consider it noteworthy to point out that parasympathetic activity predominates in younger subjects, while in older ones sympathetic and parasympathetic tones are equilibrated by a simultaneous hyperactivation of sympathetic neurons and the hypoactivation of the parasympathetic ones [67]. It is expected that these concomitant changes in the autonomic inputs have a profound effect on the modulation of heart rhythm as we age.

\section{Aging and pacemaker acceleration and deceleration at the molecular level}

The autonomic nervous system controls pacemaker action potential rate through a cascade effect of secondary pathways where the modulation of ion channels and calcium handling are the final pieces. The automaticity of the pacemaker is driven by diastolic depolarizing mechanisms that include the activation of $\mathrm{HCN}$ channels at hyperpolarized voltages, the spontaneous release of calcium from the sarcoendoplasmic reticulum through ryanodine receptors (RyR) coupled with L-type channel activation [68, 69], and the increase in the activity of the calcium sodium exchanger (NCX) [60, 70, 71]. The initial activation of the HCN channels together with the local rise in calcium depolarizes the cell enough to recruit $\mathrm{Ca}_{\mathrm{V}} 3.1$ (T-type) and $\mathrm{Ca}_{\mathrm{V}} 1.3$ (L-type) calcium channels; this further depolarization brings the membrane potential to the threshold to activate $\mathrm{Ca}_{\mathrm{V}} 1.2 \mathrm{~L}$-type calcium channels, which together with $\mathrm{Ca}_{\mathrm{V}} 1.3$ channels sustain the spike of the pacemaker action potential [72, 73]. Repolarization is mediated by the activation of potassium channels, mainly the delayed rectifier $\mathrm{K}+(\mathrm{KCNQ} 1)$ [1] and the ERG channel [74, 75].

At the molecular level, sympathetic acceleration starts by the binding of noradrenaline released from the sympathetic fibers to beta-adrenergic receptors $(\beta-\mathrm{AR})$ located in the plasma membrane of pacemaker cells [60]. $\beta$-ARs are $\mathrm{G}_{\mathrm{s}}$-coupled receptors. Their activation triggers the dissociation of the $\mathrm{G} \alpha_{\mathrm{s}}$ subunit that activates adenylyl cyclase (AC) to increase the production of cAMP [70]. It is important to note that both, $\beta 1-\mathrm{AR}$ and $\beta 2-\mathrm{AR}$, are expressed in a 1:1 ratio in pacemaker cells, indicating high expression of $\beta 2$-AR in these cells compared to ventricular cardiomyocytes [76]. While $\beta 1-\mathrm{AR}$ has been the most researched, $\beta 2$-AR is also crucial to study as it activates the same stimulatory pathway and may have additional functional responses [76-78]. Evidence showing that $\beta 1-A R$ stimulation raises global cAMP levels while $\beta 2$-AR stimulation raises local cAMP levels further suggests that these two pathways might have differential roles in pacemaker rate modulation [79].

The cAMP elevation caused by the activation of the adrenergic stimulation increases pacemaker firing rate through direct and indirect mechanisms [70]. cAMP directly binds to HCN channels, increasing their open probability and shifting their activation curve to less hyperpolarized voltages [18, $71,80]$. cAMP also acts indirectly, as a second messenger, activating protein kinase A (PKA), which phosphorylates and modulates many target proteins such as the $\alpha$ subunit of L-type calcium channels, increasing their open probability $[71,81] ; \beta$-AR receptors, decreasing desensitization; the sarcoplasmic reticulum handling protein phospholamban, increasing the rate of calcium accumulation and total storage capacity of the sarcoplasmic reticulum [82, 83]; and RyR, increasing their open probability [84]. Another important target is the phosphorylation of Ser-27 in the KCNQ1 channel, which increases the repolarization velocity, shortening the pacemaker action potential duration [85, 86].

Although phosphorylation of L-type calcium channels was proposed as the main mechanism to explain the adrenergic calcium channel facilitation [87], recent studies in ventricular cardiomyocytes have proposed an alternative mechanism for this modulation. A recent study by Liu et al. [88] showed that beta-adrenergic regulation persists on transgenic murine hearts expressing PKA phosphorylation-site-deficient mutant $\mathrm{Ca}_{\mathrm{V}} 1.2$ channels. Therefore, they propose a new mechanism that involves the PKA-mediated phosphorylation of the calcium channel inhibitor protein Rad that is tonically inhibiting calcium channels under resting conditions. Another mechanism involving the fusion of endosomes containing $\mathrm{Ca}_{\mathrm{V}} 1.2$ in response to $\beta$-AR stimulated PKA phosphorylation to increase the availability of channels at the plasma membrane has been recently proposed for ventricular cardiomyocytes by Del Villar et al. [81]. However, whether these alternative mechanisms are also present in pacemaker cells is still unknown. 
On the other hand, pacemaker deceleration at the molecular level is mediated by the release of acetylcholine from parasympathetic fibers. Acetylcholine binds to type 2 muscarinic (M2R) receptors coupled to $\mathrm{G} \alpha_{i}$ proteins that inactivate the adenylyl cyclase pathway, reducing cAMP formation and counterbalancing sympathetic drive [60]. The reduction in cAMP production causes a shift in the activationcurve of HCN channels to more negative voltages and a reduction in RyR open probability as a result of the lack of PKA-mediated phosphorylation [89, 90]. Additionally, activation of G-protein regulated potassium channels by $\mathrm{G} \beta \gamma$ subunits results in a deep hyperpolarization that accounts for $50 \%$ of the heart rate reduction $[71,91]$. Acetylcholine also activates directly $I_{\mathrm{KACh}}$ currents that results in a more negative maximal diastolic potential, decreasing the pacemaker rate $[18,71]$. Altogether, the changes induced by acetylcholine result in a negative chronotropic effect [60, 71, 92].

Aging also affects the neural control of the pacemaker at the molecular level. Pacemaker cells from old animals retain the capacity to be accelerated by adrenergic stimulation in a similar percentage to cells from young animals [3]. Accordingly, aging does not change either the transcription levels of beta-adrenergic receptors [93, 94] or the adrenergic-facilitation of calcium and HCN channels [3]. However, since old cells have a slower intrinsic firing rate, they fail to reach the same maximum firing rate as that observed in young animals, even under saturating concentrations of the beta-adrenergic agonist isoproterenol [3, 95]. Infusion of isoproterenol in patients under autonomic blockade was 39\% less efficient in accelerating heart rate in 65-year-old subjects when compared to young 25-year-old subjects [95]. This effect was also observed in ex vivo isolated pacemakers, where around 5 times more isoproterenol was needed to increase the rate by $50 \%$ [96]. In a very interesting study by Sharpe et al., it has been shown that directly activating $\mathrm{AC}$ with forskolin and at the same time inhibiting phosphodiesterase with IBMX to increase total cAMP cytoplasmic concentration failed to accelerate old pacemaker cells firing rate to the same level as young cells. However, a high concentration of exogenous cAMP completely abolished the effects of aging on the slowdown of the intrinsic firing rate, restoring action potential firing rate and $I_{\mathrm{f}}$ absolute activation to the same levels observed in young mice
[10], suggesting that all the machinery downstream AC can be potentiated to the same levels in old pacemaker cells. Other reported changes that can account for the intrinsic slowdown and the cap on the adrenergic response include a reduction in the expression of $\mathrm{Ca}_{\mathrm{V}} 1.2, \mathrm{HCN} 4, \mathrm{Na}_{\mathrm{V}} 1.5$, and several $\mathrm{K}^{+}$channels [94, 97, 98] and a persistent hyperpolarized shift in the activation of HCN channels [10].

A reduced responsivity to the parasympathetic drive has been also observed in ex vivo isolated pacemakers, where around 6 times more carbachol, a cholinergic agonist, was needed to increase the beating intervals by $50 \%$ [96]. A reduction in the expression of muscarinic receptors type 2 by $45 \%$ in old pacemaker tissue has been associated with this reduction in responsivity [93]. A reduced responsivity to the parasympathetic drive can also be attributable to a common mechanism such as a reduction of cAMP/ PKA sensitivity [99] or an age-reduced sensitivity to phosphodiesterase inhibition [96]. Parasympathetic input then appears to be attenuated in old animals, generating an abnormal sympathovagal balance with age [65].

\section{Global cardiac aging and pacemaker dysfunction}

Although the mechanisms behind the age-associated dysfunction of the cardiac pacemaker are still being elucidated, it is believed to be a multifactorial process. Besides pacemaker failure, aging is also a risk factor for the onset of other cardiomyopathies, including heart failure and atrial fibrillation [100, 101]. How these age-associated alterations of ventricular and atrial function impact the pacemaker is not known. In ventricular and atrial myocytes, aging is linked to cellular senescence, mitochondrial dysfunction, and calcium mishandling. Cardiac aging drives a loss of ventricular and atrial cells and a compensatory cellular hypertrophy [102, 103]. Cardiac senescence in heart failure and atrial fibrillation is accompanied by a general decline in mitochondrial function, characterized by clonal expansion of dysfunctional mitochondria, increased production of reactive oxygen species, and dysregulation of mitochondrial fusion and fission [104]. Calcium mishandling is perhaps one of the most prominent age-associated changes in ventricular and atrial cells. Aging causes alterations in the diastolic levels of cytoplasmic calcium, the 
sarcoplasmic reticulum calcium content, and the calcium leakage from the stores, resulting in poor excitation-contraction coupling [105].

Furthermore, while there is a close relation between the incidence of heart failure, atrial fibrillation, and pacemaker dysfunction [106], the causality of one over the other is still not clear. Heart failure is commonly associated with atrial dysfunction. The increase in left ventricular end diastolic pressure observed in heart failure patients causes an increase in the intra-atrial pressure and atrial stretch, which results in atrial electrical remodeling and atrial dilatation [107]. It has been proposed that cellular and tissue alterations caused by heart failure can also cause electrical and structural remodeling of the pacemaker [108]; the identified mechanisms so far include a decrease in the HCN4 and sodium currents [109, 110]. However, it is not clear how malfunction of the ventricular chambers can result in ionic changes of pacemaker cells. The relationship between atrial fibrillation and pacemaker dysfunction seems more reciprocate, with the appearance of atrial fibrillation being able to cause pacemaker anomalies and vice versa $[111,112]$.

Some of the age-associated ventricular alterations can be reverted using the mTOR inhibitor, rapamycin. Rapamycin treatment in old animals decreases ventricular hypertrophy and increases ejection fraction [113] and diastolic function [114]. Nevertheless, changes in heart rate have not been reported after rapamycin treatment. Whether rapamycin has the potential of ameliorating age-associated dysfunctions of the cardiac pacemaker remains elusive.

\section{Summary of the effects of age on the function and the neural control of the pacemaker}

Aging is accompanied by a natural slowdown of the pacemaker rate. In some cases, the pacemaker's slowdown becomes pathological, leading to the onset of Sick Sinus Syndrome, a group of idiopathic diseases that account for more than half of about 250,000 artificial pacemakers implanted every year in the USA. Besides the implantation of artificial devices, there is no alternative treatment for this dysfunction. Advancing our understanding of the age-associated changes in the pacemaker may inform potential novel interventions to diagnose and treat this disease. Although the mechanisms behind the dysfunction of the pacemaker are not well understood, here, we summarize the main age-associated changes on the architecture and neural control of the pacemaker that can play an important role in this phenomenon (Fig. 6). Aging is associated with the following:

- A reduction in the number of pacemaker cells.

- A reduction in the autonomic innervation.

- An increase in fibrosis. Although the role of fibrosis on the dysfunction of the pacemaker has been controversial, given the importance of cell-to-cell connectivity for the propagation of the electrical signal, it is likely that the age-associated increase in fibrosis plays an important role on reshaping pacemaker function.

- A global increase in the sympathetic drive, resulting in the release of more noradrenaline.

- A reduced responsivity of the pacemaker to adrenergic stimulation.

- A reduction in the capacity of pacemaker cells to reach optimal cytoplasmic levels of cAMP.

- Alterations in the expression and function of a variety of ion channels that are important for the automaticity and that are targets of the adrenergic modulation, including HCN, L-type, T-type, and $\mathrm{K}^{+}$channels.

- A reduction in the parasympathetic drive. These functional alterations result in an overall autonomic imbalance biased toward a higher sympathetic acceleration in the elderly.

\section{Perspectives}

The prevalence and clinical implications of the ageassociated dysfunction of the pacemaker justifies the urgency to identify the molecular mechanisms underlying it. Besides the need of defining the mechanisms for the intrinsic changes, alterations in other components of the pacemaker need more attention, including changes in the vascularization, in the generation and propagation of the electrical signal, and in the neuro-pacemaker communication.

Vascular dysfunction plays an important role in organ pathology. The brain is perhaps the most studied example, where age causes structural and functional alterations of the vascular bed leading to dysregulation of cerebral blood flow, ischemia, and 
Young pacemaker
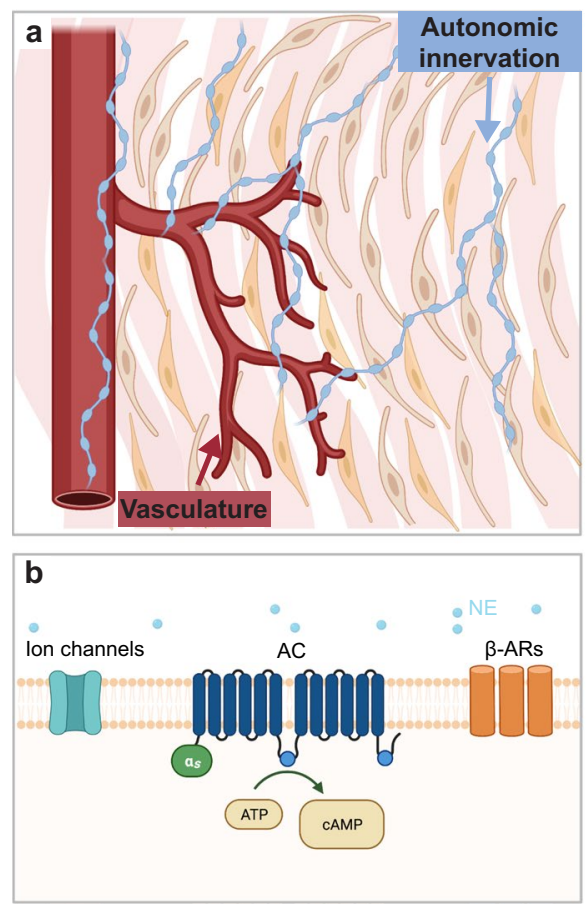

Old pacemaker
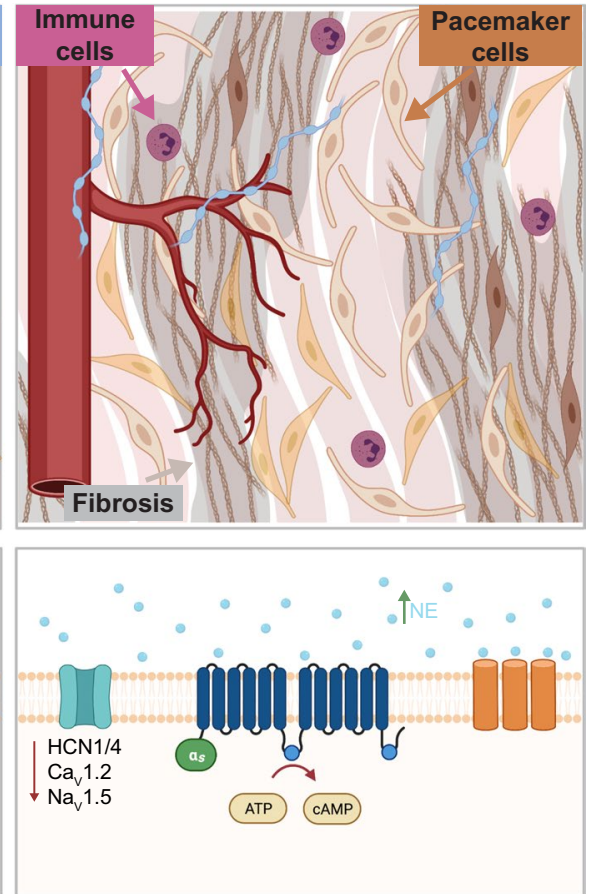

Age-associated alterations

\section{Tissue level}

Reduction in the number of pacemaker cells

Reduction of autonomic innervation

Increase in fibrosis

Vascular retraction? Infiltration of immune cells? Shift of signal origin and propagation?

\section{Cellular level}

Increase in noradrenaline release

Reduction of parasympathetic drive Reduction of responsivity to neurotransmitters

Reduction of cAMP production

Reduction of ion channel expression

Alteration of the neuro-pacemaker communication?

Fig. 6 Schematic summarizing the known and unexplored effects of age on the function and neural control of the pacemaker, emphasizing alterations at the $\mathbf{a}$ tissue and $\mathbf{b}$ cellular level. Figure created with Biorender

impaired clearance of metabolic byproducts [115]. The pacemaker is also a heavily vascularized tissue, a requisite to meet its high metabolic demands and to allow the fast control of heart rate by the action of bloodstream circulating adrenaline. Therefore, alterations in blood supply could be an important stressor that might contribute to the dysfunction of the pacemaker in the elderly.

Where in the pacemaker the action potential is originated and how it propagates inside the tissue to exit toward the atrium is fundamental for setting heart rate. The leading pacemaker site is not static, rather, in a phenomenon known as pacemaker shift, it moves from the center of the pacemaker head to the periphery or even to the tail depending on external inputs [116]. Adrenergic or cholinergic stimulation $[32,92]$, changes in extracellular ionic concentration, or the action of drugs can cause the shift of the pacemaker to the region with higher or lower sensitivity to the stimulus, depending on the excitatory or inhibitory nature of it [117]. Pacemaker shift denotes a heterogeneity in the cell identity or the molecular mechanisms that sense different stimuli. It is necessary to study how aging affects this heterogeneity to fully understand pacemaker dysfunction.

The classical view of the communication between autonomic terminals and pacemaker cells depicts the release of neurotransmitters from varicosities and the free diffusion nearby pacemaker cells [37]. However, there is evidence supporting the existence of neuro-cardiac synapses [118]. Testing the effect of aging on this neuro-pacemaker communication will require the refinement of techniques to measure the release, binding, and diffusion of noradrenaline and acetylcholine in the intact pacemaker.

Finally, another unexplored area is how cellular senescence and age-associated exacerbation of the immune response can affect pacemaker function. Growing evidence positions senescence and inflammation as important drivers for cardiac dysfunction [119-121], but how they specifically affect cardiac pacemaker function remains elusive. 
Acknowledgements This work was supported by grants from the US National Institutes of Health (CMM: R00 AG056595), the AFAR-Glenn Foundation Junior Faculty Award (CMM), and the Sagol Geromics Award (OV).

\section{Declarations}

Conflict of interest The authors declare that they have no conflict of interest.

Open Access This article is licensed under a Creative Commons Attribution 4.0 International License, which permits use, sharing, adaptation, distribution and reproduction in any medium or format, as long as you give appropriate credit to the original author(s) and the source, provide a link to the Creative Commons licence, and indicate if changes were made. The images or other third party material in this article are included in the article's Creative Commons licence, unless indicated otherwise in a credit line to the material. If material is not included in the article's Creative Commons licence and your intended use is not permitted by statutory regulation or exceeds the permitted use, you will need to obtain permission directly from the copyright holder. To view a copy of this licence, visit http://creativecommons.org/licenses/by/4.0/.

\section{References}

1. Peters $\mathrm{CH}$, Sharpe EJ, Proenza C. Cardiac pacemaker activity and aging. Annu Rev Physiol. 2020;82:21-43. https://doi.org/10.1146/annurev-physiol-021119-034453.

2. Ostchega Y, Porter KS, Hughes J, Dillon CF, Nwankwo T. Resting pulse rate reference data for children, adolescents, and adults: United States, 1999-2008. Natl Health Stat Report. 2011;41:1-16.

3. Larson ED, St Clair JR, Sumner WA, Bannister RA, Proenza C. Depressed pacemaker activity of sinoatrial node myocytes contributes to the age-dependent decline in maximum heart rate. Proc Natl Acad Sci U S A. 2013;110(44):18011-6. https://doi.org/10.1073/pnas. 1308477110.

4. Anderson JB, Benson DW. Genetics of Sick Sinus Syndrome. Card Electrophysiol Clin. 2010;2(4):499-507. https://doi.org/10.1016/j.ccep.2010.09.001.

5. Jensen PN, Gronroos NN, Chen LY, Folsom AR, deFilippi C, Heckbert SR, et al. Incidence of and risk factors for sick sinus syndrome in the general population. J Am Coll Cardiol. 2014;64(6):531-8. https://doi.org/10. 1016/j.jacc.2014.03.056.

6. Guyenet PG, Bayliss DA. Neural Control of Breathing and CO2 Homeostasis. Neuron. 2015;87(5):946-61. https://doi.org/10.1016/j.neuron.2015.08.001.

7. Levy MN. Neural control of the heart: the importance of being ignorant. J Cardiovasc Electrophysiol. 1995;6(4):283-93. https://doi.org/10.1111/j.1540-8167. 1995.tb00401.x.

8. Hutter OF, Trautwein W. Effect of vagal stimulation on the sinus venosus of the frog's heart. Nature.
1955;176(4480):512-3. https://doi.org/10.1038/17651 $2 \mathrm{a} 0$.

9. Marcus B, Gillette PC, Garson A Jr. Intrinsic heart rate in children and young adults: an index of sinus node function isolated from autonomic control. Am Heart J. 1990;119(4):911-6. https://doi.org/10.1016/s00028703(05)80331-x.

10. Sharpe EJ, Larson ED, Proenza C. Cyclic AMP reverses the effects of aging on pacemaker activity and If in sinoatrial node myocytes. J Gen Physiol. 2017;149(2):237-47. https://doi.org/10.1085/jgp.20161 1674.

11. Thery C, Gosselin B, Lekieffre J, Warembourg H. Pathology of sinoatrial node Correlations with electrocardiographic findings in 111 patients. Am Heart J. 1977;93(6):735-40. https://doi.org/10.1016/s00028703(77)80070-7.

12. Evans R, Shaw DB. Pathological studies in sinoatrial disorder (sick sinus syndrome). Br Heart J. 1977;39(7):77886. https://doi.org/10.1136/hrt.39.7.778.

13. Shiraishi I, Takamatsu T, Minamikawa T, Onouchi Z, Fujita S. Quantitative histological analysis of the human sinoatrial node during growth and aging. Circulation. 1992;85(6):2176-84. https://doi.org/10.1161/01.cir.85.6. 2176.

14. Keith A, Flack M. The Form and Nature of the Muscular Connections between the Primary Divisions of the Vertebrate Heart. J Anat Physiol. 1907;41(Pt 3):172-89.

15. Oppenheimer BS, Oppenheimer A. Nerve Fibrils in the Sino-Auricular Node. J Exp Med. 1912;16(5):613-9. https://doi.org/10.1084/jem.16.5.613.

16. Puech P, Esclavissat M, Sodi-Pallares D, Cisneros F. Normal auricular activation in the dog's heart. Am Heart J. 1954;47(2):174-91. https://doi.org/10.1016/00028703(54)90248-3.

17. Hudson RE. The human pacemaker and its pathology. Br Heart J. 1960;22:153-67. https://doi.org/10.1136/hrt. 22.2.153.

18. Boyett MR, Honjo H, Kodama I. The sinoatrial node, a heterogeneous pacemaker structure. Cardiovasc Res. 2000;47(4):658-87. https://doi.org/10.1016/s00086363(00)00135-8.

19. Csepe TA, Zhao J, Hansen BJ, Li N, Sul LV, Lim P, et al. Human sinoatrial node structure: 3D microanatomy of sinoatrial conduction pathways. Prog Biophys Mol Biol. 2016;120(1-3):164-78. https://doi.org/10.1016/j.pbiom olbio.2015.12.011.

20. De Maziere AM, van Ginneken AC, Wilders R, Jongsma HJ, Bouman LN. Spatial and functional relationship between myocytes and fibroblasts in the rabbit sinoatrial node. J Mol Cell Cardiol. 1992;24(6):567-78. https://doi. org/10.1016/0022-2828(92)91041-3.

21. Mandrioli D, Ceci F, Balbi T, Ghimenton C, Pierini G. SEM, TEM, and IHC analysis of the sinus node and its implications for the cardiac conduction system. Anat Res Int. 2013;2013: 961459. https://doi.org/10.1155/2013/ 961459.

22. DiFrancesco D. Characterization of single pacemaker channels in cardiac sino-atrial node cells. Nature. 1986;324(6096):470-3. https://doi.org/10.1038/32447 $0 \mathrm{a} 0$. 
23. Denyer JC, Brown HF. Rabbit sino-atrial node cells: isolation and electrophysiological properties. J Physiol. 1990;428:405-24. https://doi.org/10.1113/jphysiol.1990. sp018219.

24. Verheijck EE, Wessels A, van Ginneken AC, Bourier J, Markman MW, Vermeulen JL, et al. Distribution of atrial and nodal cells within the rabbit sinoatrial node: models of sinoatrial transition. Circulation. 1998;97(16):162331. https://doi.org/10.1161/01.cir.97.16.1623.

25. Masson-Pevet MA, Bleeker WK, Besselsen E, Treytel BW, Jongsma HJ, Bouman LN. Pacemaker cell types in the rabbit sinus node: a correlative ultrastructural and electrophysiological study. J Mol Cell Cardiol. 1984;16(1):53-63. https://doi.org/10.1016/s00222828(84)80714-2.

26. James TN, Sherf L, Fine G, Morales AR. Comparative ultrastructure of the sinus node in man and dog. Circulation. 1966;34(1):139-63. https://doi.org/10.1161/01.cir. 34.1.139.

27. Monfredi O, Dobrzynski H, Mondal T, Boyett MR, Morris GM. The anatomy and physiology of the sinoatrial nodea contemporary review. Pacing Clin Electrophysiol. 2010;33(11):1392-406. https://doi.org/10.1111/j.15408159.2010.02838.x.

28. Kwong KF, Schuessler RB, Green KG, Laing JG, Beyer EC, Boineau JP, et al. Differential expression of gap junction proteins in the canine sinus node. Circ Res. 1998;82(5):604-12. https://doi.org/10.1161/01.res.82.5. 604.

29. Coppen SR, Kodama I, Boyett MR, Dobrzynski H, Takagishi Y, Honjo H, et al. Connexin45, a major connexin of the rabbit sinoatrial node, is co-expressed with connexin43 in a restricted zone at the nodal-crista terminalis border. J Histochem Cytochem. 1999;47(7):907-18. https://doi.org/10.1177/002215549904700708.

30. Kreuzberg MM, Sohl G, Kim JS, Verselis VK, Willecke $\mathrm{K}$, Bukauskas FF. Functional properties of mouse connexin30.2 expressed in the conduction system of the heart. Circ Res. 2005;96(11):1169-77. https://doi.org/10. 1161/01.RES.0000169271.33675.05.

31. Iyer R, Monfredi O, Lavorato M, Terasaki M, FranziniArmstrong C. Ultrastructure of primary pacemaking cells in rabbit sino-atrial node cells indicates limited sarcoplasmic reticulum content. FASEB Bioadv. 2020;2(2):106-15. https://doi.org/10.1096/fba. 2018-00079.

32. Yanni J, Tellez JO, Sutyagin PV, Boyett MR, Dobrzynski H. Structural remodelling of the sinoatrial node in obese old rats. J Mol Cell Cardiol. 2010;48(4):653-62. https:// doi.org/10.1016/j.yjmcc.2009.08.023.

33. de Melo SR, de Souza RR, Mandarim-de-Lacerda CA. Stereologic study of the sinoatrial node of rats - age related changes. Biogerontology. 2002;3(6):383-90. https://doi.org/10.1023/a:1021376002896.

34. Ho SY, Sanchez-Quintana D. Anatomy and pathology of the sinus node. J Interv Card Electrophysiol. 2016;46(1):3-8. https://doi.org/10.1007/ s10840-015-0049-6.

35. Hao X, Zhang Y, Zhang X, Nirmalan M, Davies L, Konstantinou D, et al. TGF-betal-mediated fibrosis and ion channel remodeling are key mechanisms in producing the sinus node dysfunction associated with SCN5A deficiency and aging. Circ Arrhythm Electrophysiol. 2011;4(3):397-406. https://doi.org/10.1161/ CIRCEP.110.960807.

36. Glukhov AV, Kalyanasundaram A, Lou Q, Hage LT, Hansen BJ, Belevych AE, et al. Calsequestrin 2 deletion causes sinoatrial node dysfunction and atrial arrhythmias associated with altered sarcoplasmic reticulum calcium cycling and degenerative fibrosis within the mouse atrial pacemaker complex1. Eur Heart J. 2015;36(11):686-97. https://doi.org/10.1093/eurheartj/eht452.

37. Pauza DH, Rysevaite K, Inokaitis H, Jokubauskas M, Pauza AG, Brack KE, et al. Innervation of sinoatrial nodal cardiomyocytes in mouse. A combined approach using immunofluorescent and electron microscopy. J Mol Cell Cardiol. 2014;75:188-97. https://doi.org/10. 1016/j.yjmcc.2014.07.016.

38. Chow LT, Chow SS, Anderson RH, Gosling JA. Autonomic innervation of the human cardiac conduction system: changes from infancy to senility-an immunohistochemical and histochemical analysis. Anat Rec. 2001;264(2):169-82. https://doi.org/10.1002/ar.1158.

39. Armour JA, Murphy DA, Yuan BX, Macdonald S, Hopkins DA. Gross and microscopic anatomy of the human intrinsic cardiac nervous system. Anat Rec. 1997;247(2):289-98. https://doi.org/10.1002/(SICI) 1097-0185(199702)247:2\%3c289::AID-AR15\%3e3.0. CO;2-L.

40. Rysevaite K, Saburkina I, Pauziene N, Noujaim SF, Jalife J, Pauza DH. Morphologic pattern of the intrinsic ganglionated nerve plexus in mouse heart. Heart Rhythm. 2011;8(3):448-54. https://doi.org/10.1016/j. hrthm.2010.11.019.

41. Edwards FR, Hirst GD, Klemm MF, Steele PA. Different types of ganglion cell in the cardiac plexus of guinea-pigs. J Physiol. 1995;486(Pt 2):453-71. https:// doi.org/10.1113/jphysiol.1995.sp020825.

42. Fedele L, Brand T. The intrinsic cardiac nervous system and its role in cardiac pacemaking and conduction. J Cardiovasc Dev Dis. 2020;7(4):54. https://doi.org/10. 3390/jcdd7040054.

43. Pauza DH, Rysevaite-Kyguoliene K, Vismantaite J, Brack KE, Inokaitis H, Pauza AG, et al. A combined acetylcholinesterase and immunohistochemical method for precise anatomical analysis of intrinsic cardiac neural structures. Ann Anat. 2014;196(6):430-40. https:// doi.org/10.1016/j.aanat.2014.08.004.

44. Schmidt RE, Dorsey DA, Parvin CA, Beaudet LN. Sympathetic neuroaxonal dystrophy in the aged rat pineal gland. Neurobiol Aging. 2006;27(10):1514-23. https://doi.org/10.1016/j.neurobiolaging.2005.08.005.

45. Bellinger D, Tran L, Kang JI, Lubahn C, Felten DL, Lorton D. Age-related changes in noradrenergic sympathetic innervation of the rat spleen is strain dependent. Brain Behav Immun. 2002;16(3):247-61. https:// doi.org/10.1006/brbi.2001.0626.

46. Corbett EK, Mary DA, McWilliam PN, Batten TF. Age-related loss of cardiac vagal preganglionic neurones in spontaneously hypertensive rats. Exp Physiol. 2007;92(6):1005-13. https://doi.org/10.1113/expph ysiol.2007.038216. 
47. Saburkina I, Gukauskiene L, Rysevaite K, Brack KE, Pauza AG, Pauziene N, et al. Morphological pattern of intrinsic nerve plexus distributed on the rabbit heart and interatrial septum. J Anat. 2014;224(5):583-93. https://doi.org/10.1111/joa.12166.

48. Ai J, Gozal D, Li L, Wead WB, Chapleau MW, Wurster $\mathrm{R}$, et al. Degeneration of vagal efferent axons and terminals in cardiac ganglia of aged rats. J Comp Neurol. 2007;504(1):74-88. https://doi.org/10.1002/cne.21431.

49. Janig W. Neurocardiology: a neurobiologist's perspective. J Physiol. 2016;594(14):3955-62. https://doi.org/ 10.1113/JP271895.

50. Pilowsky PM, Goodchild AK. Baroreceptor reflex pathways and neurotransmitters: 10 years on. J Hypertens. 2002;20(9):1675-88. https://doi.org/10.1097/00004 872-200209000-00002.

51. Sundlof G, Wallin BG. Human muscle nerve sympathetic activity at rest. Relationship to blood pressure and age. J Physiol. 1978;274:621-37. https://doi.org/10.1113/jphys iol.1978.sp012170.

52. Ng AV, Callister R, Johnson DG, Seals DR. Age and gender influence muscle sympathetic nerve activity at rest in healthy humans. Hypertension. 1993;21(4):498503. https://doi.org/10.1161/01.hyp.21.4.498.

53. Hart EC, Joyner MJ, Wallin BG, Johnson CP, Curry TB, Eisenach $\mathrm{JH}$, et al. Age-related differences in the sympathetic-hemodynamic balance in men. Hypertension. 2009;54(1):127-33. https://doi.org/10.1161/HYPER TENSIONAHA.109.131417.

54. Narkiewicz K, Phillips BG, Kato M, Hering D, Bieniaszewski L, Somers VK. Gender-selective interaction between aging, blood pressure, and sympathetic nerve activity. Hypertension. 2005;45(4):522-5. https:// doi.org/10.1161/01.HYP.0000160318.46725.46.

55. Ziegler MG, Lake CR, Kopin IJ. Plasma noradrenaline increases with age. Nature. 1976;261(5558):333-5. https://doi.org/10.1038/261333a0.

56. Goldstein DS, Lake CR, Chernow B, Ziegler MG, Coleman MD, Taylor AA, et al. Age-dependence of hypertensivenormotensive differences in plasma norepinephrine. Hypertension. 1983;5(1):100-4. https://doi.org/10.1161/ 01.hyp.5.1.100.

57. Esler M, Hastings J, Lambert G, Kaye D, Jennings G, Seals DR. The influence of aging on the human sympathetic nervous system and brain norepinephrine turnover. Am J Physiol Regul Integr Comp Physiol. 2002;282(3):R909-16. https://doi.org/10.1152/ajpregu. 00335.2001 .

58. Goldberg PB, Tumer N, Roberts J. Effect of increasing age on adrenergic control of heart rate in the rat. Exp Gerontol. 1988;23(2):115-25. https://doi.org/10.1016/ 0531-5565(88)90076-9.

59. Lucini D, Cerchiello M, Pagani M. Selective reductions of cardiac autonomic responses to light bicycle exercise with aging in healthy humans. Auton Neurosci. 2004;110(1):55-63. https://doi.org/10.1016/j.autneu. 2003.10.002.

60. Gordan R, Gwathmey JK, Xie LH. Autonomic and endocrine control of cardiovascular function. World J Cardiol. 2015;7(4):204-14. https://doi.org/10.4330/wjc.v7.i4.204.
61. Rosenberg AA, Weiser-Bitoun I, Billman GE, Yaniv Y. Signatures of the autonomic nervous system and the heart's pacemaker cells in canine electrocardiograms and their applications to humans. Sci Rep. 2020;10(1):9971. https://doi.org/10.1038/s41598-020-66709-z.

62. Kuga K, Yamaguchi I, Sugishita Y. Age-related changes of sinus node function and autonomic regulation in subjects without sinus node disease-assessment by pharmacologic autonomic blockade. Jpn Circ J. 1993;57(8):760 8. https://doi.org/10.1253/jcj.57.760.

63. De Meersman RE, Stein PK. Vagal modulation and aging. Biol Psychol. 2007;74(2):165-73. https://doi.org/ 10.1016/j.biopsycho.2006.04.008.

64. Baker SE, Limberg JK, Dillon GA, Curry TB, Joyner MJ, Nicholson WT. Aging Alters the Relative Contributions of the Sympathetic and Parasympathetic Nervous System to Blood Pressure Control in Women. Hypertension. 2018;72(5):1236-42. https://doi.org/10. 1161/HYPERTENSIONAHA.118.11550.

65. Comelli M, Meo M, Cervantes DO, Pizzo E, Plosker A, Mohler PJ, et al. Rhythm dynamics of the aging heart: an experimental study using conscious, restrained mice. Am J Physiol Heart Circ Physiol. 2020;319(4):H893905. https://doi.org/10.1152/ajpheart.00379.2020.

66. Ask TF, Lugo RG, Sutterlin S. The Neuro-ImmunoSenescence Integrative Model (NISIM) on the Negative Association Between Parasympathetic Activity and Cellular Senescence. Front Neurosci. 2018;12:726. https://doi.org/10.3389/fnins.2018.00726.

67. de Marneffe M, Gregoire JM, Waterschoot P, Kestemont MP. The sinus node and the autonomic nervous system in normals and in sick sinus patients. Acta Cardiol. 1995;50(4):291-308.

68. Baig SM, Koschak A, Lieb A, Gebhart M, Dafinger C, Nurnberg G, et al. Loss of Ca(v)1.3 (CACNA1D) function in a human channelopathy with bradycardia and congenital deafness. Nat Neurosci. 2011;14(1):77-84. https://doi.org/10.1038/nn.2694.

69. Torrente AG, Mesirca P, Neco P, Rizzetto R, Dubel $\mathrm{S}$, Barrere $\mathrm{C}$, et al. L-type Cav1.3 channels regulate ryanodine receptor-dependent $\mathrm{Ca} 2+$ release during sino-atrial node pacemaker activity. Cardiovasc Res. 2016;109(3):451-61. https://doi.org/10.1093/cvr/ cvw006.

70. Vinogradova TM, Lakatta EG. Regulation of basal and reserve cardiac pacemaker function by interactions of cAMP-mediated PKA-dependent $\mathrm{Ca} 2+$ cycling with surface membrane channels. J Mol Cell Cardiol. 2009;47(4):456-74. https://doi.org/10.1016/j.yjmcc. 2009.06.014.

71. MacDonald EA, Rose RA, Quinn TA. Neurohumoral control of sinoatrial node activity and heart rate: insight from experimental models and findings from humans. Front Physiol. 2020;11:170. https://doi.org/10. 3389/fphys.2020.00170.

72. Ebert SN, Taylor DG. Catecholamines and development of cardiac pacemaking: an intrinsically intimate relationship. Cardiovasc Res. 2006;72(3):364-74. https://doi.org/10.1016/j.cardiores.2006.08.013. 
73. Mangoni ME, Nargeot J. Genesis and regulation of the heart automaticity. Physiol Rev. 2008;88(3):919-82. https://doi.org/10.1152/physrev.00018.2007.

74. Furukawa Y, Miyashita Y, Nakajima K, Hirose M, Kurogouchi F, Chiba S. Effects of verapamil, zatebradine, and E-4031 on the pacemaker location and rate in response to sympathetic stimulation in dog hearts. J Pharmacol Exp Ther. 1999;289(3):1334-42.

75. Wang L, Swirp S, Duff H. Age-dependent response of the electrocardiogram to $\mathrm{K}(+)$ channel blockers in mice. Am J Physiol Cell Physiol. 2000;278(1):C73-80. https://doi.org/10.1152/ajpcell.2000.278.1.C73.

76. Saito K, Torda T, Potter WZ, Saavedra JM. Characterization of beta 1 - and beta 2-adrenoceptor subtypes in the rat sinoatrial node and stellate ganglia by quantitative autoradiography. Neurosci Lett. 1989;96(1):35-41. https://doi.org/10.1016/0304-3940(89)90239-5.

77. de Lucia C, Eguchi A, Koch WJ. New Insights in Cardiac beta-Adrenergic Signaling During Heart Failure and Aging. Front Pharmacol. 2018;9:904. https://doi. org/10.3389/fphar.2018.00904.

78. Chesley A, Lundberg MS, Asai T, Xiao RP, Ohtani S, Lakatta EG, et al. The beta(2)-adrenergic receptor delivers an antiapoptotic signal to cardiac myocytes through G(i)-dependent coupling to phosphatidylinositol 3'-kinase. Circ Res. 2000;87(12):1172-9. https:// doi.org/10.1161/01.res.87.12.1172.

79. Wang XJ, Ma MM, Zhou LB, Jiang XY, Hao MM, Teng $\mathrm{RKF}$, et al. Autonomic ganglionic injection of alphasynuclein fibrils as a model of pure autonomic failure alpha-synucleinopathy. Nat Commun. 2020;11(1):934. https://doi.org/10.1038/s41467-019-14189-9.

80. DiFrancesco D, Tortora P. Direct activation of cardiac pacemaker channels by intracellular cyclic AMP. Nature. 1991;351(6322):145-7. https://doi.org/10. 1038/351145a0.

81. Del Villar SG, Voelker TL, Westhoff M, Reddy GR, Spooner HC, Navedo MF et al. $\beta$-Adrenergic control of sarcolemmal CaV1.2 abundance by small GTPase Rab proteins. Proc Natl Acad Sci. 2021;118(7):e2017937118. https://doi.org/10.1073/pnas.2017937118.

82. La Raia PJ, Morkin E. Phosphorylation-dephosphorylation of cardiac microsomes: a possible mechanism for control of calcium uptake by cyclic AMP. Recent Adv Stud Cardiac Struct Metab. 1974;4:417-26.

83. Tada M, Kirchberger MA, Katz AM. Phosphorylation of a 22,000-dalton component of the cardiac sarcoplasmic reticulum by adenosine 3':5'-monophosphate-dependent protein kinase. J Biol Chem. 1975;250(7):2640-7.

84. Bogdanov KY, Vinogradova TM, Lakatta EG. Sinoatrial nodal cell ryanodine receptor and $\mathrm{Na}(+)-\mathrm{Ca}(2+)$ exchanger: molecular partners in pacemaker regulation. Circ Res. 2001;88(12):1254-8. https://doi.org/10.1161/ hh1201.092095.

85. Wang X, Fitts RH. Cardiomyocyte slowly activating delayed rectifier potassium channel: regulation by exercise and beta-adrenergic signaling. J Appl Physiol. 1985;128(5):1177-85. https://doi.org/10.1152/japplphysi ol.00802.2019.
86. Kurokawa J, Motoike HK, Rao J, Kass RS. Regulatory actions of the A-kinase anchoring protein Yotiao on a heart potassium channel downstream of PKA phosphorylation. Proc Natl Acad Sci U S A. 2004;101(46):16374-8. https://doi.org/10.1073/pnas. 0405583101.

87. De Jongh KS, Murphy BJ, Colvin AA, Hell JW, Takahashi M, Catterall WA. Specific phosphorylation of a site in the full-length form of the alpha 1 subunit of the cardiac L-type calcium channel by adenosine 3',5'-cyclic monophosphate-dependent protein kinase. Biochemistry. 1996;35(32):10392-402. https://doi.org/10.1021/bi953 $023 \mathrm{c}$.

88. Liu G, Papa A, Katchman AN, Zakharov SI, Roybal D, Hennessey JA, et al. Mechanism of adrenergic CaV1.2 stimulation revealed by proximity proteomics. Nature. 2020;577(7792):695-700. https://doi.org/10.1038/ s41586-020-1947-z.

89. Marx SO, Reiken S, Hisamatsu Y, Gaburjakova M, Gaburjakova J, Yang YM, et al. Phosphorylation-dependent regulation of ryanodine receptors: a novel role for leucine/isoleucine zippers. J Cell Biol. 2001;153(4):699708. https://doi.org/10.1083/jcb.153.4.699.

90. Vinogradova TM, Bogdanov KY, Lakatta EG. betaAdrenergic stimulation modulates ryanodine receptor $\mathrm{Ca}(2+)$ release during diastolic depolarization to accelerate pacemaker activity in rabbit sinoatrial nodal cells. Circ Res. 2002;90(1):73-9. https://doi.org/10.1161/ hh0102.102271.

91. Wickman K, Nemec J, Gendler SJ, Clapham DE. Abnormal heart rate regulation in GIRK4 knockout mice. Neuron. 1998;20(1):103-14. https://doi.org/10.1016/s08966273(00)80438-9.

92. Ashton JL, Trew ML, LeGrice IJ, Paterson DJ, Paton JF, Gillis AM, et al. Shift of leading pacemaker site during reflex vagal stimulation and altered electrical source-tosink balance. J Physiol. 2019;597(13):3297-313. https:// doi.org/10.1113/JP276876.

93. Hardouin S, Bourgeois F, Toraasson M, Oubenaissa A, Elalouf JM, Fellmann D, et al. Beta-adrenergic and muscarinic receptor mRNA accumulation in the sinoatrial node area of adult and senescent rat hearts. Mech Ageing Dev. 1998;100(3):277-97. https://doi.org/10.1016/s00476374(97)00142-5.

94. Tellez JO, McZewski M, Yanni J, Sutyagin P, Mackiewicz $\mathrm{U}$, Atkinson A, et al. Ageing-dependent remodelling of ion channel and $\mathrm{Ca} 2+$ clock genes underlying sino-atrial node pacemaking. Exp Physiol. 2011;96(11):1163-78. https://doi.org/10.1113/expphysiol.2011.057752.

95. Christou DD, Seals DR. Decreased maximal heart rate with aging is related to reduced $\{$ beta\}-adrenergic responsiveness but is largely explained by a reduction in intrinsic heart rate. J Appl Physiol. 1985;105(1):24-9. https://doi.org/10.1152/japplphysiol.90401.2008.

96. Yaniv Y, Ahmet I, Tsutsui K, Behar J, Moen JM, Okamoto $\mathrm{Y}$, et al. Deterioration of autonomic neuronal receptor signaling and mechanisms intrinsic to heart pacemaker cells contribute to age-associated alterations in heart rate variability in vivo. Aging Cell. 2016;15(4):716-24. https://doi.org/10.1111/acel.12483. 
97. Jones SA, Boyett MR, Lancaster MK. Declining into failure: the age-dependent loss of the L-type calcium channel within the sinoatrial node. Circulation. 2007;115(10):1183-90. https://doi.org/10.1161/CIRCU LATIONAHA.106.663070.

98. Alghamdi AM, Boyett MR, Hancox JC, Zhang H. Cardiac pacemaker dysfunction arising from different studies of ion channel remodeling in the aging rat heart. Front Physiol. 2020;11: 546508. https://doi.org/10.3389/ fphys.2020.546508.

99. Behar J, Yaniv Y. Age-related pacemaker deterioration is due to impaired intracellular and membrane mechanisms: Insights from numerical modeling. J Gen Physiol. 2017;149(10):935-49. https://doi.org/10.1085/jgp.20171 1792.

100. Braunwald E. Shattuck lecture-cardiovascular medicine at the turn of the millennium: triumphs, concerns, and opportunities. N Engl J Med. 1997;337(19):1360-9. https://doi.org/10.1056/NEJM199711063371906.

101. Lakatta EG, Levy D. Arterial and cardiac aging: major shareholders in cardiovascular disease enterprises: Part II: the aging heart in health: links to heart disease. Circulation. 2003;107(2):346-54. https://doi.org/10.1161/01. cir.0000048893.62841.f7.

102. Olivetti G, Melissari M, Capasso JM, Anversa P. Cardiomyopathy of the aging human heart. Myocyte loss and reactive cellular hypertrophy. Circ Res. 1991;68(6):1560-8. https://doi.org/10.1161/01.res.68.6. 1560.

103. Santhanakrishnan R, Wang N, Larson MG, Magnani JW, McManus DD, Lubitz SA, et al. Atrial fibrillation begets heart failure and vice versa: temporal associations and differences in preserved versus reduced ejection fraction. Circulation. 2016;133(5):484-92. https://doi.org/10. 1161/CIRCULATIONAHA.115.018614.

104. Tocchi A, Quarles EK, Basisty N, Gitari L, Rabinovitch PS. Mitochondrial dysfunction in cardiac aging. Biochim Biophys Acta. 2015;1847(11):1424-33. https://doi.org/ 10.1016/j.bbabio.2015.07.009.

105. Shinohara T, Park HW, Han S, Shen MJ, Maruyama M, $\mathrm{Kim} \mathrm{D}$, et al. $\mathrm{Ca} 2+$ clock malfunction in a canine model of pacing-induced heart failure. Am J Physiol Heart Circ Physiol. 2010;299(6):H1805-11. https://doi.org/10.1152/ ajpheart.00723.2010.

106. Sridhar A, Nishijima Y, Terentyev D, Khan M, Terentyeva R, Hamlin RL, et al. Chronic heart failure and the substrate for atrial fibrillation. Cardiovasc Res. 2009;84(2):22736. https://doi.org/10.1093/cvr/cvp216.

107. Melenovsky V, Hwang SJ, Redfield MM, Zakeri R, Lin $\mathrm{G}$, Borlaug BA. Left atrial remodeling and function in advanced heart failure with preserved or reduced ejection fraction. Circ Heart Fail. 2015;8(2):295-303. https://doi. org/10.1161/CIRCHEARTFAILURE.114.001667.

108. Sanders P, Kistler PM, Morton JB, Spence SJ, Kalman JM. Remodeling of sinus node function in patients with congestive heart failure: reduction in sinus node reserve. Circulation. 2004;110(8):897-903. https://doi.org/10. 1161/01.CIR.0000139336.69955.AB.

109. Verkerk AO, Wilders R, Coronel R, Ravesloot JH, Verheijck EE. Ionic remodeling of sinoatrial node cells by heart failure. Circulation. 2003;108(6):760-6. https:// doi.org/10.1161/01.CIR.0000083719.51661.B9.

110. Chang SL, Chuang HL, Chen YC, Kao YH, Lin YK, Yeh YH, et al. Heart failure modulates electropharmacological characteristics of sinoatrial nodes. Exp Ther Med. 2017;13(2):771-9. https://doi.org/10.3892/etm.2016. 4015.

111. Hadian D, Zipes DP, Olgin JE, Miller JM. Short-term rapid atrial pacing produces electrical remodeling of sinus node function in humans. J Cardiovasc Electrophysiol. 2002;13(6):584-6. https://doi.org/10.1046/j. 1540-8167.2002.00584.x.

112. Kezerashvili A, Krumerman AK, Fisher JD. Sinus node dysfunction in atrial fibrillation: cause or effect? J Atr Fibrillation. 2008;1(3):30. https://doi.org/10.4022/jafib. 30.

113. Flynn JM, O'Leary MN, Zambataro CA, Academia EC, Presley MP, Garrett BJ, et al. Late-life rapamycin treatment reverses age-related heart dysfunction. Aging Cell. 2013;12(5):851-62. https://doi.org/10.1111/acel.12109.

114. Quarles E, Basisty N, Chiao YA, Merrihew G, Gu H, Sweetwyne MT, et al. Rapamycin persistently improves cardiac function in aged, male and female mice, even following cessation of treatment. Aging Cell. 2020;19(2): e13086. https://doi.org/10.1111/acel.13086.

115. Fulop GA, Tarantini S, Yabluchanskiy A, Molnar A, Prodan CI, Kiss T, et al. Role of age-related alterations of the cerebral venous circulation in the pathogenesis of vascular cognitive impairment. Am J Physiol Heart Circ Physiol. 2019;316(5):H1124-40. https://doi.org/10.1152/ ajpheart.00776.2018.

116. Schuessler RB, Boineau JP, Bromberg BI. Origin of the sinus impulse. J Cardiovasc Electrophysiol. 1996;7(3):263-74. https://doi.org/10.1111/j.1540-8167. 1996.tb00524.x.

117. Beau SL, Hand DE, Schuessler RB, Bromberg BI, Kwon $\mathrm{B}$, Boineau JP, et al. Relative densities of muscarinic cholinergic and beta-adrenergic receptors in the canine sinoatrial node and their relation to sites of pacemaker activity. Circ Res. 1995;77(5):957-63. https://doi.org/10. 1161/01.res.77.5.957.

118. Klemm M, Hirst GD, Campbell G. Structure of autonomic neuromuscular junctions in the sinus venosus of the toad. J Auton Nerv Syst. 1992;39(2):139-50. https:// doi.org/10.1016/0165-1838(92)90054-k.

119. Li H, Hastings MH, Rhee J, Trager LE, Roh JD, Rosenzweig A. Targeting Age-Related Pathways in Heart Failure. Circ Res. 2020;126(4):533-51. https://doi.org/10.1161/ CIRCRESAHA.119.315889.

120. Moro-Garcia MA, Echeverria A, Galan-Artimez MC, Suarez-Garcia FM, Solano-Jaurrieta JJ, Avanzas-Fernandez $\mathrm{P}$, et al. Immunosenescence and inflammation characterize chronic heart failure patients with more advanced disease. Int J Cardiol. 2014;174(3):590-9. https://doi.org/10.1016/j.ijcard.2014.04.128.

121. Baker DJ, Childs BG, Durik M, Wijers ME, Sieben CJ, Zhong J, et al. Naturally occurring p16(Ink4a)positive cells shorten healthy lifespan. Nature. 2016;530(7589):184-9. https://doi.org/10.1038/natur e16932. 
122. Osadchii OE. Reduced intrinsic heart rate is associated with reduced arrhythmic susceptibility in guinea-pig heart. Scand Cardiovasc J. 2014;48(6):357-67. https:// doi.org/10.3109/14017431.2014.976256.

123. Noujaim SF, Lucca E, Munoz V, Persaud D, Berenfeld O, Meijler FL, et al. From mouse to whale: a universal scaling relation for the PR Interval of the electrocardiogram of mammals. Circulation. 2004;110(18):2802-8. https://doi.org/10.1161/01.CIR.0000146785.15995.67.

124. Jiang M, Murias JM, Chrones T, Sims SM, Lui E, Noble EG. American ginseng acutely regulates contractile function of rat heart. Front Pharmacol. 2014;5:43. https://doi. org/10.3389/fphar.2014.00043.

125. Mischke K, Zarse M, Knackstedt C, Schauerte P. Rate control in atrial fibrillation by cooling: effect of temperature on dromotropy in perfused rabbit hearts. Cardiol Res Pract. 2011;2011: 162984. https://doi.org/10.4061/2011/ 162984.

126. Peper ES, Leopaldi AM, van Tuijl S, Coolen BF, Strijkers GJ, Baan J Jr, et al. An isolated beating pig heart platform for a comprehensive evaluation of intracardiac blood flow with 4D flow MRI: a feasibility study. Eur Radiol Exp. 2019;3(1):40. https://doi.org/10.1186/ s41747-019-0114-5.

127. Baudot M, Torre E, Bidaud I, Louradour J, Torrente AG, Fossier L, et al. Concomitant genetic ablation of L-type Cav1.3 (alpha1D) and T-type Cav3.1 (alpha1G) $\mathrm{Ca}(2+)$ channels disrupts heart automaticity. Sci Rep. 2020;10(1):18906. https://doi.org/10.1038/ s41598-020-76049-7.

128. Opthof T. The normal range and determinants of the intrinsic heart rate in man. Cardiovasc Res. 2000;45(1):173-6.

129. Mangoni ME, Traboulsie A, Leoni AL, Couette B, Marger L, Le Quang K, et al. Bradycardia and slowing of the atrioventricular conduction in mice lacking CaV3.1/alpha1G T-type calcium channels. Circ Res. 2006;98(11):1422-30. https://doi.org/10.1161/01.RES. 0000225862.14314 .49 .
130. Bolter CP, Atkinson KJ. Maximum heart rate responses to exercise and isoproterenol in the trained rat. Am J Physiol. 1988;254(5 Pt 2):R834-9. https://doi.org/10. 1152/ajpregu.1988.254.5.R834.

131. Woulfe KC, Wilson CE, Nau S, Chau S, Phillips EK, Zang S, et al. Acute isoproterenol leads to age-dependent arrhythmogenesis in guinea pigs. Am J Physiol Heart Circ Physiol. 2018;315(4):H1051-62. https://doi.org/10. 1152/ajpheart.00061.2018.

132. Lang D, Petrov V, Lou Q, Osipov G, Efimov IR. Spatiotemporal control of heart rate in a rabbit heart. J Electrocardiol. 2011;44(6):626-34. https://doi.org/10.1016/j. jelectrocard.2011.08.010.

133. Fox SM 3rd, Naughton JP, Haskell WL. Physical activity and the prevention of coronary heart disease. Ann Clin Res. 1971;3(6):404-32.

134. Semelka M, Gera J, Usman S. Sick sinus syndrome: a review. Am Fam Physician. 2013;87(10):691-6.

135. Monfredi O, Boyett MR. Sick sinus syndrome and atrial fibrillation in older persons - A view from the sinoatrial nodal myocyte. J Mol Cell Cardiol. 2015;83:88-100. https://doi.org/10.1016/j.yjmcc.2015.02.003.

136. Huang X, Yang P, Yang Z, Zhang H, Ma A. Age-associated expression of $\mathrm{HCN}$ channel isoforms in rat sinoatrial node. Exp Biol Med (Maywood). 2016;241(3):331-9. https://doi.org/10.1177/1535370215603515.

137. Jones SA, Lancaster MK, Boyett MR. Ageing-related changes of connexins and conduction within the sinoatrial node. J Physiol. 2004;560(Pt 2):429-37. https://doi.org/10.1113/jphysiol.2004.072108.

138. Alings AM, Bouman LN. Electrophysiology of the ageing rabbit and cat sinoatrial node-a comparative study. Eur Heart J. 1993;14(9):1278-88. https://doi.org/10. 1093/eurheartj/14.9.1278.

Publisher's note Springer Nature remains neutral with regard to jurisdictional claims in published maps and institutional affiliations. 